\title{
Do periarticular dense bone islands cause cartilage destruction?
}

\author{
Periartiküler dens kemik adaları kıkırdak yıkımına neden olur mu?
}

\author{
O. Şahap Atik, M.D., Nil Tokgöz, M.D. \\ 'Department of Orthopaedics and Traumatology, Medical Faculty of Gazi University, Ankara, Turkey \\ ${ }^{2}$ Department of Radiology, Medical Faculty of Gazi University, Ankara, Turkey
}

Articular cartilage problems of the knee are common. ${ }^{[1]}$ There are several conditions causing cartilage defects, and there are many options for management. ${ }^{[2,3]}$

An enostosis or bone island represents a focus of mature compact (cortical) bone within the cancellous bone. ${ }^{[4]}$ The "dense bone island" (DBI) is a radiopaque lesion referred to in the literature as idiopathic osteosclerosis, enostosis, focal osteosclerosis, periapical osteopetrosis, and bone scar. ${ }^{[5]}$ The DBI is probably congenital or developmental in origin, and reflects failure of resorption during endochondral ossification. ${ }^{[4]}$ The lesion is usually asymptomatic. It is accidentally found in routine X-rays of bones, anywhere in the skeleton; pelvis, spine, femur, and other long bones.

Radiography reveals a homogeneously dense, sclerotic focus in the cancellous bone. A bone island appears as a low-attenuation focus on computed tomography (CT) scan, it shows low signal intensity like cortical bone on MRI sequences, and is usually "cold" on skeletal scintigraphy. ${ }^{[4]}$

Histopathologically, DBIs are composed of dense calcified tissue without marrow spaces and generally no inflammatory cell infiltration. ${ }^{[6]}$ They are generally small in size and do not change over time. ${ }^{[7]}$ It is recommended that an open biopsy of a bone island should be obtained if the lesion's growth exceeds $25 \%$ of its diameter within six months or $50 \%$ within one year. ${ }^{[8]}$
Bone islands may be differentiated from more aggressive or malignant bone lesions by one of the following:

- Absence of a primary tumor,

- Slow growth over a period of years,

- A clearly demarcated margin with thorny radiations from the sclerotic lesion, or

- Absence of pain. ${ }^{[6]}$

The erosion of cartilage has recently been challenged as the primary pathological mechanism of osteoarthritis and the subchondral bone has been suggested to play a key role. The subchondral bone plate is in direct contact with the cartilage, and could influence its degradation. ${ }^{[9]}$ There is strong evidence that bone marrow lesions and bone cysts have an important role in the pathogenesis of knee osteoarthritis. ${ }^{[10]}$ Bone marrow lesions consist of a number of heterogenous histologic abnormalities including bone marrow necrosis, trabecular abnormalities, bone marrow fibrosis and edema. ${ }^{[1]]}$ Bone marrow lesions including dense bone islands may cause decrease of the elasticity in subchondral bone.

In conclusion, we suggest that dense bone islands may play a key role in the initiation and progression of erosion in cartilage. This effect may be increased when the bone marrow lesion (dense bone island) is bifocal as seen in Figure 1.

- Received: January 04, 2013 Accepted: February 12, 2013

- Correspondence: O. Şahap Atik, M.D. Gazi Üniversitesi Tıp Fakültesi Ortopedi ve Travmatoloji Anabilim Dalı, 06500 Beşevler, Ankara, Turkey Tel: +90 312 - 2025528 Fax: +90 312 - 2129008 e-mail: satikmd@gmail.com 

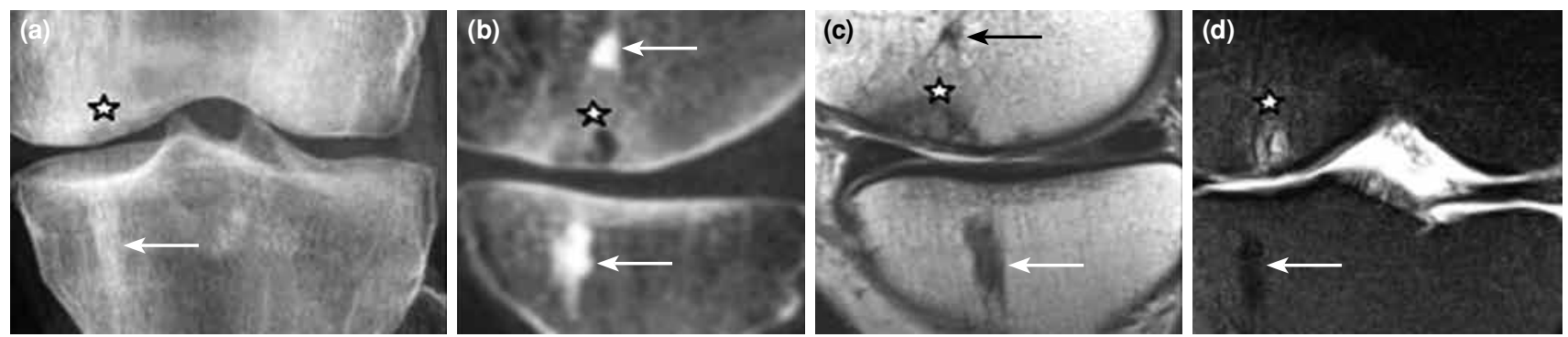

Figure 1. Anteroposterior radiograph of the left knee (a) shows a focal radiolucent area (star) in the medial femoral condyle which is suspicious for osteochondral lesion. There is also a sclerotic, ovoid intramedullary lesion (arrow) in the medial proximal tibial subchondral region consistent with dense a bone island. Computed tomography scan (b), $\mathrm{T}_{1}$-weighted (c), and fat-suppressed $\mathrm{T}_{2}$-weighted coronal (d) MR images reveal the sclerotic bone islands (arrows) on both sides of the medial knee joint, and the osteochondral lesion (star) which is "sandwiched" between these lesions.

\section{Declaration of conflicting interests}

The author declared no conflicts of interest with respect to the authorship and/or publication of this article.

\section{Funding}

The author received no financial support for the research and/or authorship of this article.

\section{REFERENCES}

1. Curl WW, Krome J, Gordon ES, Rushing J, Smith BP, Poehling GG. Cartilage injuries: a review of 31,516 knee arthroscopies. Arthroscopy 1997;13:456-60.

2. Atik OS, Takka S, Satana T, et al. Osteochondral multiple autograft transfer (OMAT). Eklem Hastalik Cerrahisi 1996;7:1-2.

3. Atik OS. Can we obtain hyaline cartilage with currently available techniques? Eklem Hastalik Cerrahisi 2010;21:1.

4. Greenspan A. Bone island (enostosis): current concept-a review. Skeletal Radiol 1995;24:111-5.

5. Mariani GC, Favaretti F, Lamazza L, DE Biase A. Dense bone island of the jaw: a case report. Oral Implantol (Rome) 2008;1:87-90.

6. Nakano K, Ogawa T, Sobue S, Ooshima T. Dense bone island: clinical features and possible complications. Int J Paediatr Dent 2002;12:433-7.

7. Greenspan A, Stadalnik RC. Bone island: scintigraphic findings and their clinical application. Can Assoc Radiol J 1995;46:368-79.

8. Mirra JM. Enostosis. Bone tumor. Philadelphia: Lea \& Febiger; 1989. p. 182-91.

9. Martel-Pelletier J, Pelletier JP. Is osteoarthritis a disease involving only cartilage or other articular tissues? Eklem Hastalik Cerrahisi 2010;21:2-14.

10. Raynauld JP, Martel-Pelletier J, Berthiaume MJ, Abram F, Choquette D, Haraoui B, et al. Correlation between bone lesion changes and cartilage volume loss in patients with osteoarthritis of the knee as assessed by quantitative magnetic resonance imaging over a 24 -month period. Ann Rheum Dis 2008;67:683-8.

11. Zanetti M, Bruder E, Romero J, Hodler J. Bone marrow edema pattern in osteoarthritic knees: correlation between MR imaging and histologic findings. Radiology 2000;215:835-40. 